\title{
Increasing the Compressive Strength of Portland Cement Concrete Using Flat Glass Powder
}

\author{
Edson Jansen Pedrosa de Miranda Júnior*, Helton de Jesus Costa Leite Bezerra, \\ Flávio Salgado Politi, Antônio Ernandes Macêdo Paiva \\ Department of Mechanics and Materials - DMM, Federal Institute of Education, \\ Science and Technology of Maranhão - IFMA, São Luís, MA, Brazil
}

Received: June 20, 2013; Revised: April 13, 2014

\begin{abstract}
This paper analyzes the compressive strength of Portland cement concrete in response to the incorporation of $5 \%, 10 \%$ and $20 \%$ of flat glass powder in place of sand, at w/c (water/cement) ratios of $0.50,0.55$ and 0.58 . A statistical analysis of variance (ANOVA) was performed after 7, 14 and 28 days of curing. The compressive strength test results indicate that the concrete containing a w/c ratio of 0.50 can be used for structural applications, regardless of the waste glass content, as can that with a w/c ratio of 0.55 containing $20 \%$ of waste glass. We suggest that the use of flat glass powder in place of sand in the abovementioned percentages is feasible for the production of an environmentally appropriate and structurally applicable concrete. However, the concrete's fluidity and void content must be taken into account.
\end{abstract}

Keywords: Portland cement concrete, waste glass, flat glass powder, fine aggregate, compressive strength test

\section{Introduction}

Millions of tons of industrial wastes potentially usable in civil construction are produced in Brazil today. According to the Brazilian Association of Solid Waste Treatment Companies (ABETRE), $76 \%$ of these wastes are discarded in landfills, $18 \%$ are co-processed in clinker furnaces, $3 \%$ are incinerated or subjected to other thermal processes, and $3 \%$ are treated biologically or with other technologies ${ }^{1}$. In Brazil, waste glass corresponds to an average of $2.4 \%$ $(1,332,827 \mathrm{t} /$ year $)$ of all urban wastes ${ }^{2}$.

Brazil produces an average of $980,000 \mathrm{t}$ of glass packaging per year, using approximately $45 \%$ of raw materials in the form of recycled glass shards. Part of this waste is generated as scrap in factories and the remainder returns through selective waste collection. Only $47 \%$ of all glass packaging produced in 2011 was recycled ${ }^{3}$.

The use of glass as a fine aggregate in Portland cement concrete has been studied and some countries currently use this material. Australia, for instance, has been using ground waste glass in concrete for civil constructions. Recommendations have been made for the use of this material in concrete in the state of New York. This resource is rarely considered valuable in Brazil because landfilling is a cheaper option and raw materials for use in construction are abundantly available ${ }^{4}$.

The main focus of research has been the use of waste glass in place of cement and, in a few cases, as fine and coarse aggregate for concrete. Only a few studies have focused on the use of waste glass as a fine aggregate in concrete for structural purposes. Some examples are the studies of Azevedo ${ }^{5}$, López et al. ${ }^{4}$ and Miranda $\mathrm{Jr}^{6}$.

Taha $\&$ Nounu $^{7}$ examined the feasibility of using recycled glass sand and pozzolanic glass powder in concrete

*e-mail: edson.jansen@ifma.edu.br in place of sand and cement, respectively. These authors used ground granulated blast furnace slag and metakaolin in place of Portland cement, and investigated the effect of recycled glass sand on the behavior and properties of concrete containing blends of different cementitious materials. They observed no significant differences in the compressive strength of concrete as a result of the presence of recycled glass sand, but reported an average decrease of $16 \%$ when $20 \%$ of Portland cement was substituted for pozzolanic glass powder.

The purpose of this study was to analyze the influence of partially substituting natural fine aggregate for flat glass powder on the compressive strength of Portland cement concrete. One of the differentials of this research was the use of flat glass powder. This is the first study focusing on the application of this type of waste glass as fine aggregate in Portland cement concrete.

This article complements another study by the authors ${ }^{8}$, underpinning the results of the physical properties of Portland cement concrete containing flat glass powder as fine aggregate.

\section{Experimental}

\subsection{Material}

The Portland cement used was pozzolanic CP IV-32 RS produced by Nassau, because concrete made with it is less permeable and particularly because it reduces the reactivity of the alkali-silica reaction (ASR).

Washed river sand was used as fine aggregate and crushed stone as coarse aggregate, the former supplied by Itapera Mineração Ltda. and the latter by Brita Prado, both located in the city of São Luís, state of Maranhão. 
The waste glass was supplied by the tempered glass manufacturer Marvite, and came from the flat sheet glass grinding and polishing process prior to the glass tempering process.

\subsection{Methods}

Initially, the waste glass was ground and oven-dried at $110{ }^{\circ} \mathrm{C}$. Next, the waste glass was characterized by its particle size distribution, X-ray diffraction (XRD) and energy-dispersive X-ray fluorescence spectroscopy (EDXRF).

The concrete was prepared using a mix of 1:1.57:1.935:w/c ratio, (cement:sand:crushed stone: water/ cement ratio). Note that no type of additive was used to homogenize the mixture. Waste glass percentages of 5\%, $10 \%$ and $20 \%$ in place of sand and $\mathrm{w} / \mathrm{c}$ ratios of $0.50,0.55$ and 0.58 were used in the preparation of the concrete.

Cylindrical test specimens $(10 \mathrm{~cm}$ x $20 \mathrm{~cm})$ were molded and cured as recommended by the Brazilian technical standard NBR 5738 ${ }^{9}$. The samples were consolidated manually in two layers, applying 15 strokes of the tamping rod to each layer of concrete. The test specimens were first cured for 24 hours in the molds at an ambient temperature of $28.5^{\circ} \mathrm{C}$. They were then released from the molds and immersed in water at $26.5^{\circ} \mathrm{C}$ to cure for 7,14 and 28 days.

The results of the compressive strength test were subjected to a statistical analysis of variance (ANOVA).

\subsubsection{Compressive strength test}

The compressive strength test was applied to the molded concrete test specimens containing the three w/c ratios and the three percentages of waste glass in substitution of sand, which were cured for 7, 14 and 28 days. Nonconfined polychloroprene elastomer (known commercially as Neoprene) with 70 Shore A hardness was used on the test specimens instead of capping, as recommended by the ASTM C1231 standard ${ }^{10}$.

The compressive strength tests were performed in an Emic DL30000N universal testing machine with a load capacity of $300 \mathrm{kN}$, with loading applied at a constant rate of $0.5 \mathrm{MPa} / \mathrm{s}$, as recommended by the Brazilian NBR 5738 standard ${ }^{9}$.

\subsubsection{X-ray diffraction (XRD)}

After being fractured in the compressive strength test, the 28-day-old test specimens containing a w/c ratio of 0.50 and $0 \%$ and $20 \%$ of waste glass were crushed with a mortar and pestle for subsequent identification of their crystalline phases by XRD. The crushed fraction of these analyzed test specimens contained no coarse aggregate.

The concrete and waste glass were analyzed by X-ray diffraction in a Brucker X-ray diffractometer (DO Focus, Germany) at the Federal University of São Carlos - UFSCar. XRD measurements of the waste glass were taken at room temperature in the interval of $4^{\circ}$ to $8^{\circ}$ and of concrete in the interval of $20^{\circ}$ to $80^{\circ}$, using $\mathrm{CuK} \alpha$ radiation $(\lambda=15406)$, a step size of $0.02^{\circ}$, a Ni filter, a voltage of $40 \mathrm{kV}$, and an emission current of $40 \mathrm{~mA}$. The crystalline phases were identified by comparing the XRD data with the SearchMatch database.

\section{Results and Discussion}

\subsection{Characterization of raw material}

Figure 1 compares the particle size distribution of sand and waste glass. The percentage of pulverulent waste glass (material finer than $0.075 \mathrm{~mm}$ ) was $6.74 \%$. This percentage is more than two-fold higher that obtained for the fine aggregate, which was $3.15 \%$. A high percentage of waste glass fines may cause the water absorption to increase, thus impairing the cement hydration process.

Because the fineness modulus of glass is higher than that of fine aggregate, its particles are larger, which was confirmed by the predominance of glass particle sizes of $300 \mu \mathrm{m}$ to $4.74 \mathrm{~mm}$. Note that the waste glass presented lower percentages of material passing through the sieves with $300 \mu \mathrm{m}$ and $600 \mu \mathrm{m}$ openings than the sand.

Figure 2 presents the XRD diffractogram of the waste glass. Note the non-crystalline state of this material, which shows the formation of broad bands within a wide scanning interval of $4^{\circ}$ to $80^{\circ}$, which are typical of glassy materials.

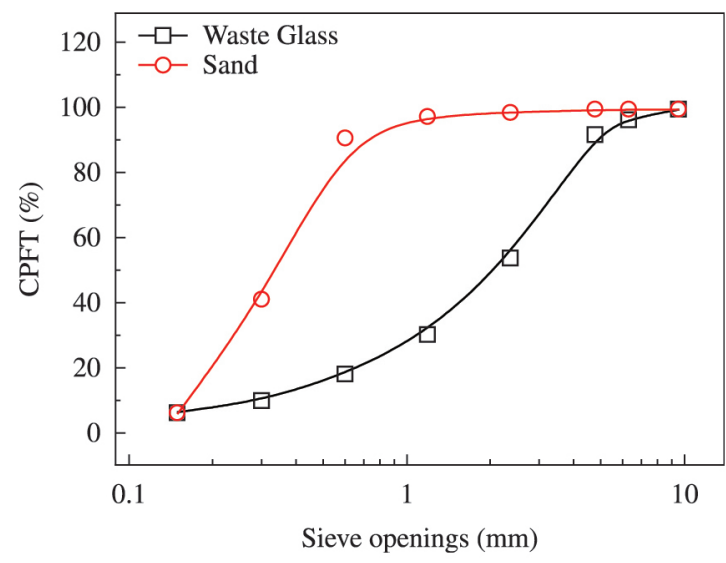

Figure 1. Comparative particle size distribution of sand and waste glass.

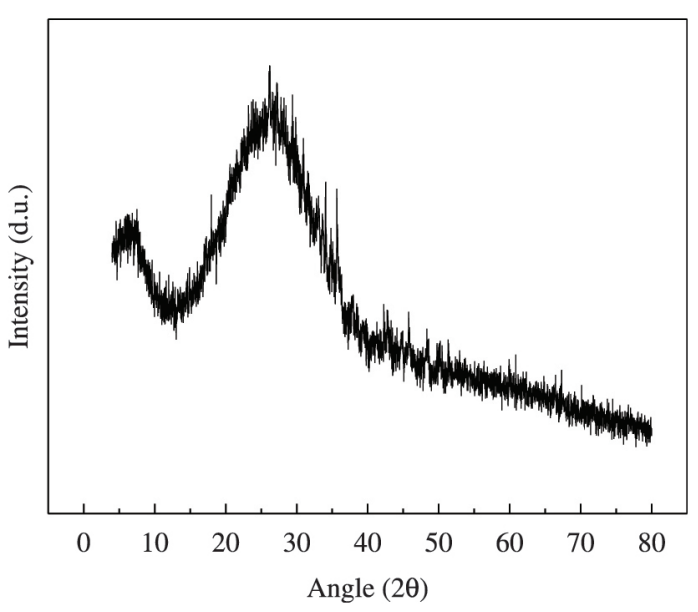

Figure 2. XRD diffractogram of waste glass. 
Tables 1 and 2 describe the results of the chemical analysis of the waste glass and cement by EDXRF. As can be seen, $\mathrm{Si}$ and $\mathrm{Ca}$ predominate as the most abundant elements.

\subsection{Compressive strength test}

Tables 3, 4 and 5 list the ANOVA results of the compressive strength data of the concrete as a function of w/c ratios and percentages of glass at 7, 14 and 28 days of curing, respectively.

Table 1. Chemical analysis of waste glass by EDXRF.

\begin{tabular}{cc}
\hline \multicolumn{3}{c}{ Waste Glass } \\
\hline Element & Percentage (\%) \\
\hline $\mathrm{Si}$ & 49.986 \\
$\mathrm{Ca}$ & 41.847 \\
$\mathrm{Fe}$ & 2.119 \\
$\mathrm{~S}$ & 1.938 \\
$\mathrm{Al}$ & 1.335 \\
$\mathrm{Mg}$ & 0.970 \\
$\mathrm{~K}$ & 0.839 \\
$\mathrm{Ti}$ & 0.322 \\
$\mathrm{Cu}$ & 0.299 \\
$\mathrm{Sr}$ & 0.148 \\
$\mathrm{Zr}$ & 0.114 \\
$\mathrm{Zn}$ & 0.083 \\
\hline
\end{tabular}

Table 2. Chemical analysis of CP IV-32 RS Portland cement by EDXRF.

\begin{tabular}{cc}
\hline \multicolumn{2}{c}{ Portland Cement } \\
\hline Element & Percentage (\%) \\
\hline $\mathrm{Ca}$ & 71.337 \\
$\mathrm{Si}$ & 11.304 \\
$\mathrm{Fe}$ & 7.892 \\
$\mathrm{Al}$ & 4.045 \\
$\mathrm{~S}$ & 2.550 \\
$\mathrm{Ti}$ & 1.060 \\
$\mathrm{~K}$ & 0.860 \\
$\mathrm{Mn}$ & 0.638 \\
$\mathrm{Sr}$ & 0.103 \\
$\mathrm{~V}$ & 0.083 \\
$\mathrm{Zr}$ & 0.077 \\
$\mathrm{Cu}$ & 0.029 \\
\hline
\end{tabular}

Based on the ANOVA, it can be concluded that the hypothesis of the averages being equal was rejected and that the effects of the w/c ratio, percentage of glass and the interaction between them are significant at a $5 \%$ level of significance at all the concrete curing ages.

Figures 3, 4, 5, 6, 7 and 8 illustrate the influence of glass percentage and w/c ratio on the concrete's compressive strength at each of the three curing ages. As can be seen these figures, the aforementioned variables significantly

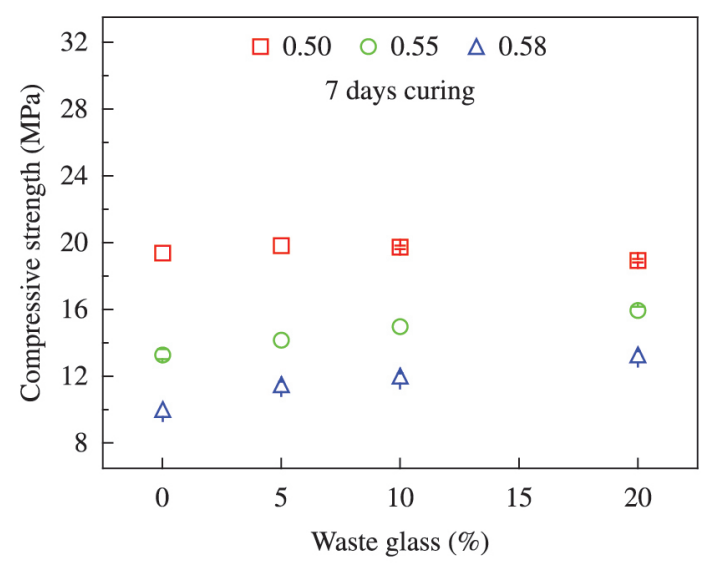

Figure 3. Compressive strength as a function of glass percentage after 7 days of curing.

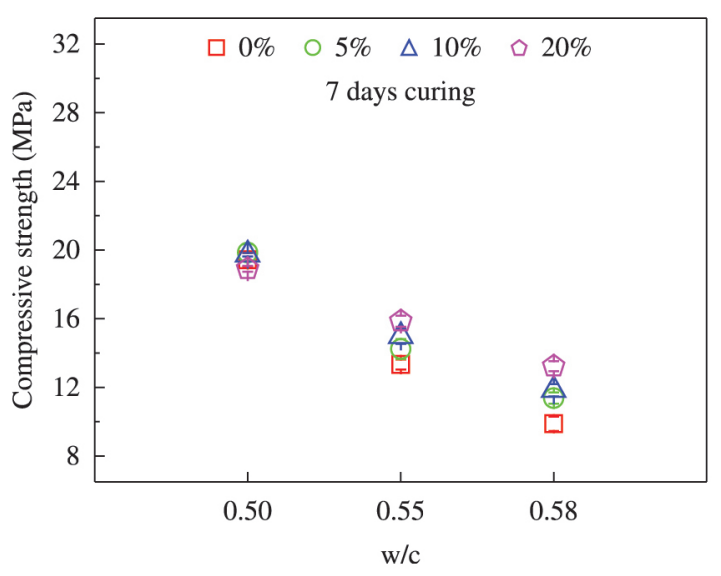

Figure 4. Compressive strength as a function of the w/c ratio after 7 days of curing.

Table 3. ANOVA values of the compressive strength test to determine the effects of the w/c ratio and waste glass percentage after 7 days of curing.

\begin{tabular}{ccccccc}
\hline & \multicolumn{3}{c}{ ANOVA } & & \\
\hline Variation & $\mathbf{D F}^{*}$ & $\mathbf{S Q}^{* *}$ & $\mathbf{A S}^{* * * *}$ & $\mathbf{F}_{\text {exp. }}$ & $\mathbf{F}_{\text {cri. }}$ & Value of p \\
\hline w/c & 2 & 381.12365 & 190.56183 & 458.50381 & 3.40 & 0 \\
\% of glass & 3 & 15.47677 & 5.15892 & 12.41269 & 3.01 & $4.22588 \mathrm{E}-5$ \\
Interaction & 6 & 13.68808 & 2.28135 & 5.48907 & 2.51 & 0.00107 \\
Model & 11 & 410.2885 & 37.29895 & 89.74364 & 2.215 & $1.11022 \mathrm{E}-16$ \\
Residue & 24 & 9.9748 & 0.41562 & -- & -- & -- \\
Total & 35 & 420.2633 & -- & -- & -- \\
\hline
\end{tabular}


Table 4. ANOVA values of the compressive strength test to determine the effects of the w/c ratio and waste glass percentage after 14 days of curing.

\begin{tabular}{ccccccc}
\hline \multicolumn{7}{c}{ ANOVA } \\
\hline Variation & DF & SQ & AS & $\mathbf{F}_{\text {exp. }}$ & F $_{\text {cri. }}$ & Value of $\mathbf{p}$ \\
\hline w/c & 2 & 189.62047 & 94.81023 & 134.10533 & 3.40 & $9.42579 \mathrm{E}-14$ \\
\% of glass & 3 & 17.0525 & 5.68417 & 8.04003 & 3.01 & $7.0095 \mathrm{E}-4$ \\
Interaction & 6 & 18.87651 & 3.14609 & 4.45001 & 2.51 & 0.00367 \\
Model & 11 & 225.54948 & 20.5045 & 29.0028 & 2.215 & $3.4803 \mathrm{E}-11$ \\
Residue & 24 & 16.9676 & 0.70698 & -- & -- & -- \\
Total & 35 & 242.51708 & -- & -- & -- \\
\hline
\end{tabular}

Table 5. ANOVA values of the compressive strength test to determine the effects of the w/c ratio and waste glass percentage after 28 days of curing.

\begin{tabular}{ccccccc}
\hline \multicolumn{7}{c}{ ANOVA } \\
\hline Variation & DF & SQ & AS & F $_{\text {exp. }}$ & F $_{\text {cri. }}$ & Value of p \\
\hline w/c & 2 & 424.66072 & 212.33036 & 726.04676 & 3.40 & 0 \\
\% of glass & 3 & 7.16762 & 2.38921 & 8.1697 & 3.01 & $6.38573 \mathrm{E}-4$ \\
Interaction & 6 & 13.70993 & 2.28499 & 7.81333 & 2.51 & $9.77917 \mathrm{E}-5$ \\
Model & 11 & 445.53827 & 40.50348 & 138.49842 & 2.215 & 0 \\
Residue & 24 & 7.01873 & 0.29245 & -- & -- & -- \\
Total & 35 & 452.557 & -- & -- & - & - \\
\hline
\end{tabular}

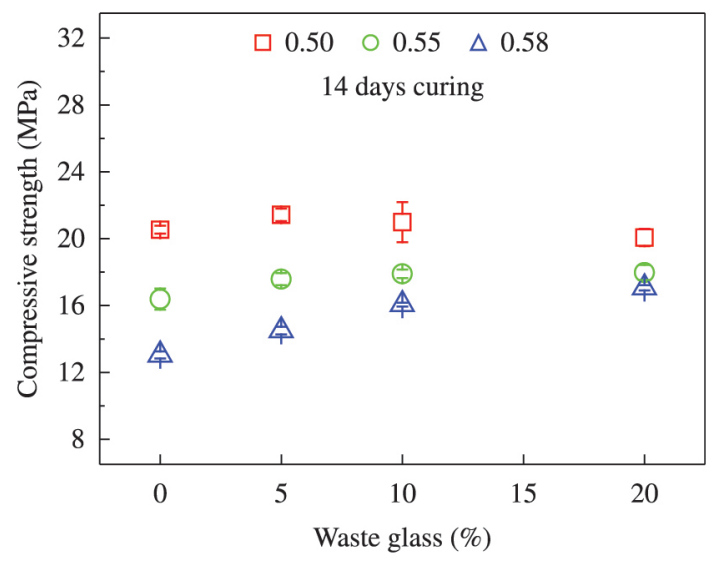

Figure 5. Compressive strength as a function of glass percentage after 14 days of curing.

affected the compressive strength of the concrete at each of the analyzed curing ages, although the variable w/c ratio exerted the greater influence. The same behavior was observed by Larrard \& Sedran ${ }^{11}$.

Increasing the percentage of glass in place of sand caused the compressive strength to increase $e^{4,7,12-15}$, independently of the curing age, at the w/c ratios of 0.55 and 0.58 . This behavior is ascribed to the reduction of the void ratio due to a possible improvement in the particle size distribution of the waste glass and natural fine aggregate and to the pozzolanic activity of the waste glass. Waste glass can act as a pozzolanic material, reacting with portlandite, which leads to the formation of C-S-H, reducing the voids in concrete.

However, increasing the waste glass content of the concrete prepared with the w/c ratio of 0.50 reduced

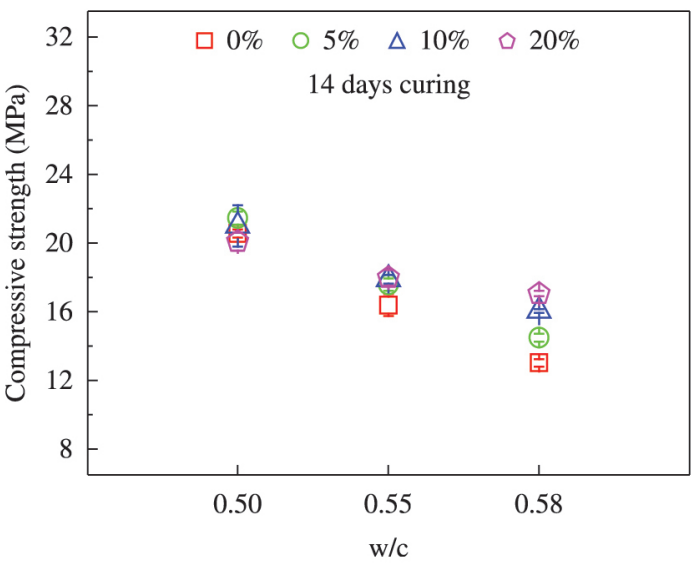

Figure 6. Compressive strength as a function of the w/c ratio after 14 days of curing.

its compressive strength ${ }^{16-18}$, although the compressive strength increased with a waste glass content of $0 \%$ to $5 \%$. This behavior is attributed to the poor fluidity of concrete containing $10 \%$ and $20 \%$ of waste glass and a w/c ratio of 0.50 , which caused the void ratio of the concrete to increase. According to Polley ${ }^{19}$, when the quantity of glass and the glass particle size is increased, more water is needed for the mixture to maintain a given workability, resulting in a lower compressive strength.

The graphs in Figures 3, 4, 5, 6, 7 and 8 also show other expected behaviors, such as the increase in compressive strength as a function of increasing curing age and reduction of the w/c ratio.

Considering the classification proposed by Mehta and Monteiro $^{20}$, the concrete showed a moderate compressive strength which makes it suitable for structural applications 


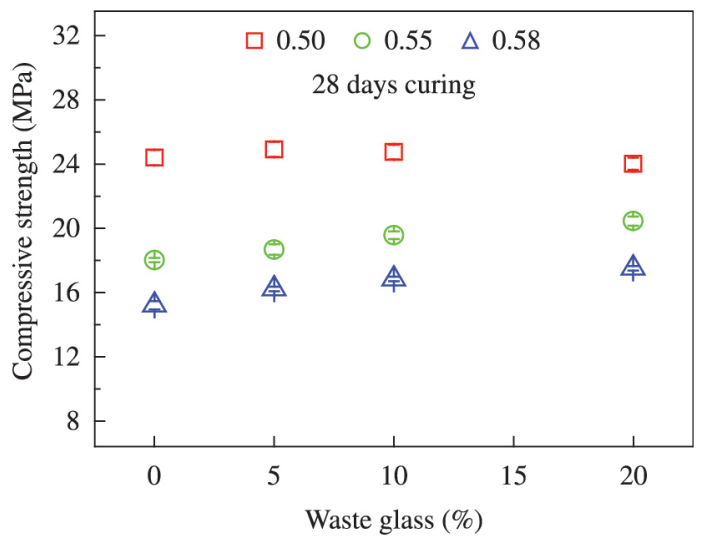

Figure 7. Compressive strength as a function of glass percentage after 28 days of curing.

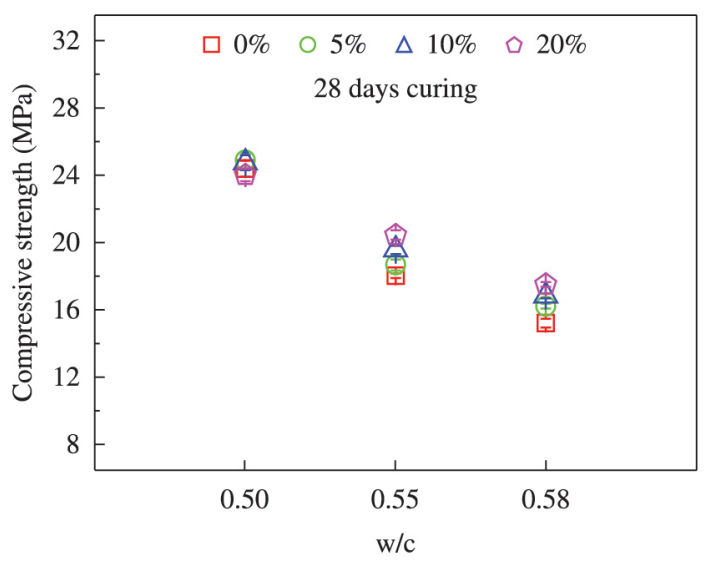

Figure 8. Compressive strength as a function of the w/c ratio after 28 days of curing.

in civil construction when prepared with a w/c ratio of 0.50 , independently of the percentage of waste glass, and with a w/c ratio of 0.55 and a waste glass content of $20 \%$.

\section{3. $X$-ray diffraction $(X R D)$}

Figures 9 and 10 show the XRD patterns of concrete containing $0 \%$ and $20 \%$ of glass, respectively, at the w/c ratio of 0.50 . In these figures, note that there is no qualitative difference in the mineralogical profile of the concrete with and without waste glass.

However, the XRD diffractogram of the concrete with a glass content of $20 \%$ was influenced by the waste glass, which was confirmed by the presence of noise, since glass is a non-crystalline material.

The XRD diffractogram of the concrete with and without waste glass showed the presence of several mineral groups, such as the normal components of concrete (quartz $-\mathrm{SiO}_{2}$, calcite $-\mathrm{CaCO}_{3}$ and calcium silicates), hydration products (ettringite $\left.-\mathrm{Ca}_{6}\left(\mathrm{Al}(\mathrm{OH})_{6}\right)_{2}\left(\mathrm{SO}_{4}\right)_{3}\left(\mathrm{H}_{2} \mathrm{O}\right)_{26}\right)$ and mineral binders (portlandite $-\mathrm{Ca}(\mathrm{OH})_{2}$ and gypsum $\mathrm{CaSO}_{4} \cdot 2 \mathrm{H}_{2} \mathrm{O}$ ).

\section{Conclusion}

In this study, the compressive strength of Portland cement concrete was found to increase in response to the

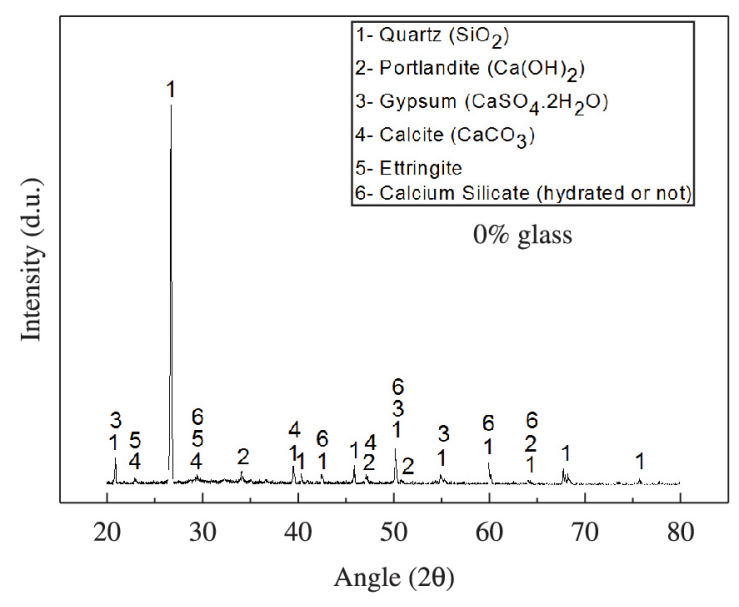

Figure 9. XRD diffractogram of concrete with $0 \%$ glass content and a w/c ratio of 0.50 .

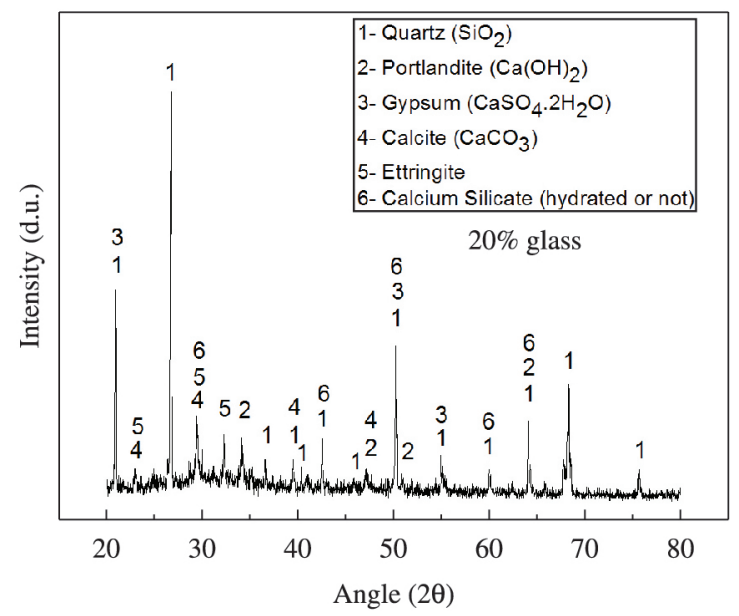

Figure 10. XRD diffractogram of concrete with $20 \%$ glass content and a w/c ratio of 0.50 .

use of waste flat glass powder, which has so far not been used as fine aggregate. The concrete containing flat glass powder was found to be suitable for structural applications when prepared with a w/c ratio of 0.55 and waste glass content of $20 \%$, and with a w/c ratio of 0.50 , regardless of the percentage of glass used. The w/c ratio of 0.50 showed the best potential when substituting sand for waste glass.

The results of the ANOVA analysis confirmed the significant influence of the $w / c$ ratio and percentage of waste glass on the compressive strength of concrete cured for 7,14 and 28 days. In addition, it was found that the compressive strength of the concrete was more influenced by the w/c ratio than by the percentage of waste glass in substitution of sand. No formation of new phases was detected in the XRD diffraction results.

The findings presented indicate the promising potential of using flat glass powder as a fine aggregate in Portland cement concrete for the production of an environmentally friendly and structurally applicable concrete. However, restrictions regarding concrete fluidity and void content should be analyzed in future studies. 


\section{Acknowledgments}

The authors gratefully acknowledge the financial support of this investigation by the Brazilian research

\section{References}

1. Del Bel D, Salgosa A. A importância da infraestrutura de destinação de resíduos sólidos. Saneas. 2012; 43:17-19.

2. Associação Brasileira de Empresas de Limpeza Pública e Resíduos Especiais. Panorama dos Resíduos Sólidos no Brasil. 2011. Available from: <http://www.abrelpe.org.br/ panorama_apresentacao.cfm>. Access in: 01/01/2014.

3. Brasil. Compromisso Empresarial para reciclagem. Vidros: o mercado para reciclagem. Available from: <http://www. cempre.org.br/ft_vidros.php >. Access in: 01/01/2014.

4. López DAR, Azevedo CAP, Barbosa EN. Avaliação das propriedades físicas e mecânicas de concretos produzidos com vidro cominuído como agregado fino. Cerâmica. 2005; 51:318324. http://dx.doi.org/10.1590/S0366-69132005000400003

5. Azevedo CA. Avaliação da utilização de vidro cominuído como material agregado ao concreto. [Dissertação]. Canoas: Universidade Luterana do Brasil, 2002.

6. Miranda Jr EJP. Propriedades físico-mecânicas do concreto de cimento Portland contendo resíduo vítreo como agregado miúdo. [Dissertação]. São Luís: Instituto Federal de Educação, Ciência e Tecnologia do Maranhão, 2012.

7. Taha B, Nounu G. Properties of concrete contains mixed colour waste recycled glass as sand and cement replacement. Construction and Building Materials. 2008; 22:713-720. http:// dx.doi.org/10.1016/j.conbuildmat.2007.01.019

8. Miranda Jr EJP, Paiva AEM, Rodrigues ENL. Influence of waste glass on the physical properties of Portland cement concrete. Journal of Materials Science Forum. 2014. Accepted for publication.

9. Associação Brasileira de Normas Técnicas. NBR 5738: Concreto - Procedimento para moldagem e cura dos corposde-prova. Rio de Janeiro: ABNT; 2003.

10. American Society for Testing And Materials. ASTM C1231/ C1231M - 10a: Standard Practice for Use of Unbonded Caps in Determination of Compressive Strength of Hardened Concrete Cylinders. Philadelphia: ASTM; 2010. funding agency CAPES (Federal Agency for the Support and Improvement of Higher Education) and by IFMA (Federal Institute of Education, Science and Technology of Maranhão).

11. Larrard F, Sedran T. Mixture-proportioning of high-performance concrete. Cement and Concrete Research. 2002; 32:1699-1704. http://dx.doi.org/10.1016/S0008-8846(02)00861-X

12. Limbachiya MC. Bulk engineering and durability properties of washed glass sand concrete. Construction and Building Materials. 2009; 23:1078-1083. http://dx.doi.org/10.1016/j. conbuildmat.2008.05.022

13. Perkins GD. Development of concrete containing waste glass. In: Proceedings of the 3rd Research Student Workshop; 2008; Pontypridd. Pontypridd: University of Glamorgan; 2008. p. $78-80$

14. Shayan A, Xu A. Value-added utilisation of waste glass in concrete. Cement and Concrete Research. 2004; 34:81-89. http://dx.doi.org/10.1016/S0008-8846(03)00251-5

15. Turgut P, Yahlizade ES. Research into concrete blocks with waste glass. International Journal of Civil and Environmental Engineering. 2009; 1:203-209.

16. Meyer C, Egosi N, Andela C. Concrete with Waste Glass as Aggregate. In: Proceedings of the International Symposium Concrete Technology Unit of ASCE and University of Dundee, Recycling and Re-use of Glass Cullet; 2001. University of Dundee; 2001. p. 19-20.

17. Park SB, Lee BC, Kim JH. Studies on mechanical properties of concrete containing waste glass aggregate. Cement and Concrete Research. 2004; 34:2181-2189. http://dx.doi. org/10.1016/j.cemconres.2004.02.006

18. Kou SC, Poon CS. Properties of self-compacting concrete prepared with recycled glass aggregate. Cement \& Concrete Composites. 2009; 31:107-113. http://dx.doi.org/10.1016/j. cemconcomp.2008.12.002

19. Polley C. The effects of waste glass aggregate on the strength and durability of Portland cement concrete. [Thesis]. Madison: University of Wisconsin, 1996.

20. Mehta PK, Monteiro PJM. Concreto: microestrutura, propriedades e materiais. 3rd ed. São Paulo: IBRACON, 2008. 